\title{
PEMBERDAYAAN FOTO WISATA UNTUK PENINGKATKAN MINAT DAN KETERAMPILAN MENULIS DESKRIPSI PADA SISWA KELAS IV SD 5 LAU
}

\author{
Mulyono $^{凶}$ \\ SD 5 Lau Dawe Kudus
}

\section{Info Artikel Abstract}

Sejarah Artikel:

Diterima: 29 Des 2017

Direvisi: 20 Mar 2018

Dipublikasikan: Jun 2018

Keywords:

Interests, Writing skills,

Empowerment of photo

\begin{abstract}
The purpose of this research is to describe teacher's effort in improving the students' will and writing skills through the photos of vacation visits as a learning media of writing descriptive paragraphs done by the students of 4 grade, Lau 5 elementary school in the second semester in 2016/2017. The method that is used is class action research, and done in two cycles. The procedures in the each cycle are: planning, doing action, observation, and reflecting. The method of collecting data uses test and observation. While the technique of analyzing data uses the technique of qualitative descriptive analyze.

The result of this research shows that through the photos of students' vacation visits as a learning media, can improve the will and the writing skills. That can be seen by the achievement of the indicator research success rate, and the improvement of learning descriptive writing from the first cycle is 70 and the second cycle is 80 . While the achievement of individually learning success in the first cycle is $65 \%$ and the second cycle is $90 \%$. The students' will in joining the study also improves, it's shown from the result achievement of research score, the students' will in the each indicator, from score 3,5 "enough" category, becomes score 4 "very good" category. From this research, can be concluded that the use of vacation visits photos as the media of writing descriptive essay can improve the will and the learning skills of the 4 grade students of Lau 5 elementary school, in the second semester in 2016/2017.
\end{abstract}

\begin{abstract}
Abstrak
Penelitian ini bertujuan untuk mendeskripsikan upaya guru dalam meningkatkan minat dan keterampilan menulis siswa melalui pemberdayaan foto hasil kunjungan wisata sebagai media pembelajaran menulis paragraf deskripsi di kelas IV SD 5 Lau semester genap tahun 2016/2017. Metode Penelitian yang digunakan adalah penelitian tindakan kelas yang dilaksanakan dua siklus. Prosedur dalam tiap siklus terdiri atas perencanaan, pelaksanaan tindakan, observasi dan refleksi. Metode Pengumpulan data menggunakan tes dan observasi. Sedangkan teknik analisis data menggunakan teknik analisis deskriptif kualitatif. Hasil penelitian ini menunjukkan bahwa melalui pemberdayaan foto hasil kunjungan wisata siswa sebagai media pembelajaran terbukti dapat meningkatkan minat dan keterampilan menulis. Hal tersebut dapat dilihat dengan tercapainya indikator keberhasilan penelitian dan adanya peningkatan ratarata prestasi belajar menulis deskripsi dari siklus I sebesar 77 dan 80 pada siklus II. Sedangkan pencapaian ketuntasan belajar individual siklus I sebesar $65 \%$ dan siklus II $90 \%$. Minat siswa dalam mengikuti pembelajaran juga terlihat semakin meningkat terbukti dari hasil pencapaian skor pengamatan minat siswa pada tiap indikator dari rerata skor 3,5 kategori cukup menjadi 4 kategori Amat baik. Dari penelitian ini dapat disimpulkan bahwa Pemberdayaan foto hasil kunjungan wisata sebagai media menulis karangan deskripsi dapat meningkatkan minat dan keterampilan belajar siswa kelas IV SD 5 Lau semester genap tahun 2016/2017.
\end{abstract}

(C) 2018 Universitas Muria Kudus
p-ISSN 2087-9385

e-ISSN 2528-696X 


\section{PENDAHULUAN}

Pembelajaran menulis sangat penting dalam dunia pendidikan karena dalam kegiatan menulis dapat berlatih berbagai hal, seperti berpikir kritis, merasakan dan menikmati bermacam-macam komunikasi, memecahkan masalah, memperdalam daya tangkap, serta berlatih menyusun pengalaman dengan urutan yang logis. Akan tetapi, semua guru belum mampu menyajikan materi menulis secara menarik,inspiratif, dan kreatif. Berdasarkan pengalaman yang peneliti ketahui bahwa pembelajaran Bahasa Indonesia di SD 5 Lau hanya berorientasi pada hasil tulisan. Guru tidak menyediakan media dan sumber belajar. Siswa mengarang tanpa proses mengamati, mengidentifikasi, dan menganalisis objek yang dijadikan sumber karangan. Teknik ini mengutamakan produk yang berupa tulisan. pembahasan hasil kerja siswa jarang dilakukan . Itulah sekilas gambaran tentang pembelajaran menulis yang mengemuka di SD 5 Lau.

Model pembelajaran tersebut selain kurang menarik minat dan perhatihan siswa, juga menghambat kreativitas siswa karena objek yang akan ditulis terasa abstrak, tak tergapai, bahkan membingungkan. Siswa sulit menemukan apa yang harus ditulis dan sulit menentukan bagaimana cara menuangkan dalam bentuk tulisan. Siswa menjadi kurang berminat dan tidak termotivasi untuk menulis. Penemuan peneliti pada hasil ulangan mengarang siswa kelas empat, dengan Kriteria Ketuntasan Minimal (KKM) 75, rata-rata ketuntasan klasikal masih di bawah KKM yaitu 6,8. Rendahnya keterampilan menulis tersebut memotivasi Peneliti untuk melakukan Penelitian Tindakan Kelas (PTK).

Pemberdayaan foto hasil kunjungan objek wisata sebagai media selain mudah diperoleh dan murah, pemanfaatan foto sebagai media sangat dianjurkan para ahli pendidikan karena foto yang kelihatan diam sebenarnya banyak berkata bagi mereka yang peka dan penuh imanjinasi. Foto dapat menarik dan merangsang siswa untuk berkreasi. Mengarang melalui media foto berarti melatih dan mempertajam daya imajinasi siswa Tarigan (2010:60). Peneliti berinisiatif memanfaatkan foto hasil kunjungan wisata sebagai media pembelajaran karena (a) foto hasil kunjungan wisata, tersedia di Perpustakaan sekolah, (b) foto hasil kunjungan wisata, dapat mengingat kembali kesan yang pernah dilakukan saat berwisata bersama-sama, (c) foto hasil kunjungan wisata sangat mudah untuk diceritakan kembali tentang kisah yang tertangkap pada objek, (d) foto yang berwarnawarni dapat menarik perhatian siswa karena indah, (e) foto mengandung makna yang sangat beragam sehingga dengan mengamati foto, siswa dapat mengembangkan imajinasi dan kreativitas secara maksimal untuk merumuskan hasil pengamatannya ke dalam bentuk kalimat topik, subtopik, hingga judul dan kerangka karangan.

Berdasarkan identifikasi permasalahan diatas prioritas dari penelitian ini adalah bagaimanakah efektifitas foto hasil kunjungan wisata dapat meningkatkan kemampuan menulis paragraf deskripsi pada siswa kelas IV SD 5 Lau? Dan apakah pemanfaatan media foto dapat meningkatkan keterampilan menulis siswa kelas IV SD 5 Lau Semester II tahun 2016/2017?

\section{METODE PENELITIAN}

\section{a. Desain Prosedur Perbaikan Pembelajaran}

Desain penelitian yang digunakan yakni desain putaran spiral yang dikembangkan oleh Kemmis \& Mc Taggart (Kasbolah 2009: 113). Dengan sistem spiral yang dimulai dengan perencanaan, tindakan, pengamatan, dan refleksi. Penelitian ini menggunakan desain penelitian (PTK) dengan dua siklus, yakni proses tindakan siklus I dan siklus II bertujuan untuk mengetahui kemampuan siswa dalam menulis paragraf deskripsi melalui media foto kunjungan wisata sebagai medianya. Siklus I digunakan sebagai refleksi untuk melaksanakan siklus II. Hasil tindakan siklus II bertujuan untuk mengetahui peningkatan keterampilan menulis paragraf deskripsi melalui media foto kunjungan wisata setelah melakukan perbaikan dalam kegiatan pembelajaran yang berdasar dari siklus I. Tiap siklus terdiri dari empat tahap, yaitu perencanaan, pelaksanaan, observasi dan refleksi. Untuk memperjelas prosedur pelaksanaan tindakan kelas dapat digambarkan sebagai berikut: 


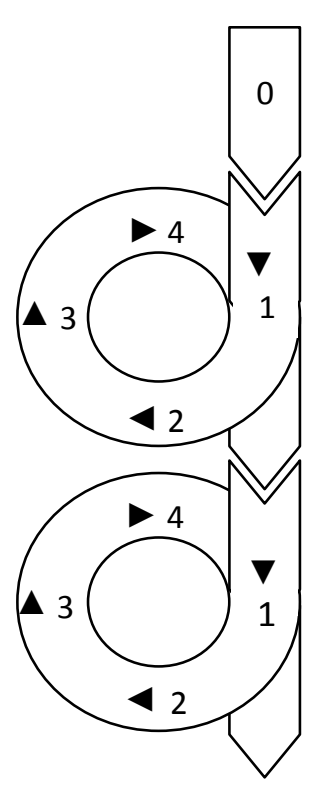

Bagan 1: Penelitian tindakan model spiral (Kemmis \& Taggart 2010: 114)

Keterangan

Siklus I : 1. Perencanaan I
2. Tindakan I
3. Observasi I
4. Refleksi I

Siklus II : 1. Perencanaan II

2. Tindakan II

3. Observasi II

4. Refleksi II

\section{Proses Tindakan Siklus I}

\subsection{Perencanaan.}

Perencanaan meliputi pembuatan rancangan rencana pembelajaran siklus I. Melalui langkah tersebut peneliti dibantu teman sejawat, dalam menyusun rancangan PTK dengan urutan sebagai berikut: (1) menyusun perangkat pembelajaran, (2) mengelompokkan peserta didik menjadi 4 kelompok, tiap kelompok terdiri dari 5 peserta didik, (3) membuat skenario pembelajaran dengan melibatkan peserta didik yang pandai sebagai pembimbing, (4) menyiapkan lembar observasi peserta didik, (5) menyusun soal-soal untuk tugas kelompok, (6) menyusun soal-soal untuk tugas rumah,v(7) menyiapkan buku daftar nilai, (8) menyiapkan alat peraga foto kunjungan wisata, (9) menentukan aturan main secara santun dalam kelompok saat berdiskusi.

\subsection{Pelaksanaan Tindakan}

Penelitian ini dilaksanakan berdasarkan prinsip-prinsip PTK dengan menerapkan siklus- siklus tindakan. Adapun langkah-langkah pelaksanaan tindakan sebagai berikut: (1) guru mengkondisikan peserta didik dengan salam dan berdo`a, (2) guru menyampaikan tujuan pembelajaran, (3) menyampaikan apersepsi, (4) melalui diskusi dengan teman sebangku, peserta didik mengamati gambar tentang kegiatan sehari-hari yang sudah dibagikan oleh guru selajutnya menentukan topik dan dari foto hasil kunjungan wisata peserta didik tersebut, (5) peserta didik dapat mengembangkan subtopik sesuai dengan situasi gambar, (6) peserta didik dapat merumuskan kalimat topik berdasarkan objek yang diamati, (7) peserta didik dapat menyusun kerangka paragraf melalui analisis dari topik ke subtopik dan pengembanganya sehingga menjadi sebuah kalimat kerangka yang runtut, (8) peserta didik dapat menyusun kalimat utama pada tiap paragraf, (9) peserta didik bersama guru, menyunting kalimat topik dan kerangka karangan sesuai EYD, (10) peserta didik mengerjakan tes formatif, (11) peserta didik bersama guru membahas hasil kerja, (12) mengadakan tindak lanjut berdasarkan hasil kerja peserta didik berupa perbaikan, pengayaan dan PR, (13) guru menutup pelajaran dengan berdoa.

\subsection{Pengamatan / Observasi}

Observasi yaitu mengamati proses pembelajaran dan menilai hasil proses pembelajaran melalui lembar pengamatan, sehingga diketahui hasilnya. Atas dasar hasil tersebut digunakan untuk merencanakan tindakan pada siklus berikutnya. Pengamatan dilakukan selama proses berlangsung siklus I, dari tahap apersepsi sampai pelaksanaan evaluasi. Dalam tahap pengamatan, penulis dibantu teman sejawat untuk memberikan penilaian terhadap proses pembelajaran dengan berpedoman pada lembar penilaian dan berdasarkan ketercapaian indikator, lembar pengamatan karakter mandiri, lembar pengamatan aktivitas guru dalam pembelajaran. Pemberian nilai berdasarkan kriteria penilaian yang ditetapkan, pengamat memberikan nilai dengan skor 5 kriteria amat baik, 4 kriteria baik dan 3 kriteria cukup baik, 2 kriteria kurang dan 1 kriteria sangat kurang. Adapun hasil dari ulangan formatif pada kompetensi dasar menulis paragraf deskripsi pada siklus I diperoleh data sebagai berikut: (a) nilai tertinggi 90, (b) nilai terendah 70, (c) nilai rata-rata 77, (d) jumlah peserta didik yang tuntas 13 atau $65 \%$, (e) jumlah peserta didik yang tidak tuntas 7 atau $35 \%$. 


\subsection{Refleksi}

Berdasarkan hasil observasi, dari segi proses pembelajaran dapat disimpulkan bahwa ada siswa yang pasif selama diskusi kelompok berlangsung. Siswa tersebut diam, tidak bertanya, tidak mengemukakan gagasan atau usul, tetapi aktif menulis. Pada waktu berdiskusi ada beberapa siswa yang mendominasi pembicaraan. Menulis dengan memanfaatkan foto kunjungan wisata siswa sebagai media pembelajaran merupakan pengalaman baru bagi siswa sehingga mereka cenderung mengamati foto untuk menikmati keindahannya. Ada pula siswa yang saling menukarkan foto dengan teman di dekatnya karena objeknya (gambarnya) menarik. Baru setelah diingatkan guru, mereka mulai mengamati dan menganalisis foto untuk kegiatan pembelajaran. Pada waktu diskusi kelompok dimulai, suasana kelas agak gaduh karena semua siswa berebut untuk melihat foto yang dijadikan objek penulisan teman sekelompoknya. Hasil tes formatif telah memenuhi target pencapaian indikator penelitian $\geq 75 \%$ yaitu pada siklus I pencapaian ketuntasan sampai $65 \%$. Penyempurnaan pembelajaran pada siklus Tindakan II mengenai hal-hal sebagai berikut: (1) memperbaiki rencana tindakan berdasarkan temuan pada siklus tindakan I, (2) meningkatkan partisipasi siswa dalam diskusi kelompok selama pembelajaran berlangsung, (3) menerapkan tata tertib dan santun berdiskusi secara benar.

\section{Proses Tindakan Siklus II}

Proses tindakan siklus II kelanjutan dari siklus I. Langkah yang dilakukan pada siklus II sama denga siklus I. Perbedaanya terletak pada penyempurnaan pelaksanaan yang didapat pada siklus I. Adapun langkah-langkahnya sebagai berikut:

\subsection{Tahap Perencanaan}

Langkah perencanaan meliputi: (1) membuat Rencana Perbaikan Pembelajaran siklus II (RPP siklus II), (b) menyusun rencana kerja kelompok/tiap kelompok mengadakan pengamatan terhadap objek gambar pada foto wisata (manusia, hewan, tumbuhan, bendabenda, profesi kerja, pemandangan alam), (c) membuat draf tentang topik dan sub topik yang dapat dirumuskan berdasarkan gambar objek pada foto, (d) mengumpulkan hasil draf tentang topik dan sub topik pada guru, (e) menyiapkan bahan ajar, (f) menyiapkan lembar kerja peserta didik, (g) Menyiapkan lembar pengamatan (guru, aktivitas siswa, karakter mandiri, pada siklus II, (h) menyiapkan alat evaluasi, (i) menyiapkan dokumen portofolio, menyiapkan pekerjaan rumah (PR)

\subsection{Pelaksanaan Tindakan}

Langkah-langkah pelaksanaan perbaikan siklus II meliputi: (1) guru mengkondisikan peserta didik dengan salam dan berdo'a, (2) mengabsen kehadiran peserta didik, (3) mempersiapkan materi bahan ajar, media dan alat penilaian, (4) guru menyampaikan kompetensi dasar dan tujuan pembelajaran setelah pembelajaran usai diharapkan peserta didik dapat menulis paragraf deskripsi melalui objek gambar yang diamati, (5) apersepsi, guru mengecek kemampuan prasyarat dengan peserta didik dengan cara tanya jawab dengan prinsip $5 \mathrm{~W}+1 \mathrm{H}$ (apa, siapa, mengapa, di mana, bagaimana, apa sebab) dengan memperhatikan foto-foto hasil kunjungn wisata peserta didik, (6) melalui membaca contoh karangan deskripsi, peserta didik menyebutkan ciri-ciri karangan deskripsi, (7) berdasarkan pengamataan foto peserta didik dapat menentukan subtopik dari sebuah objek foto yang diamati dengan menentukan bagian -bagianya (manusia, hewan, tumbuhan, benda-benda lainya), (8) peserta didik dapat menyusun kerangka paragraf melalui analisis dari topik ke subtopik dan pengembanganya sehingga menjadi sebuah kalimat kerangka yang runtut, (9) peserta didik dapat menyusun kalimat pengembang pada tiap paragraf, (10) peserta didik dapat memilih diksi berdasarkan gambar objek, (11) peserta didik dapat menyunting kalimat paragraf sesuai EYD, (12) peserta didik dapat menyusun paragraf sehingga membentuk karangan utuh, (13) peserta didik menuliskan judul karangan yang tepat untuk karangan yang ditulisnya, (14) peserta didik bersama guru, menyunting kalimat paragraf sesuai EYD, (15) menyusun karangan deskripsi berdasarkan hasil penyuntingan diksi, (16) guru bersama siswa menarik kesimpulan, (17) peserta didik mengerjakan tes formatif, (18) peserta didik bersama guru membahas hasil kerja/umpan balik, (19) mengadakan tindak lanjut berdasarkan hasil kerja peserta didik berupa perbaikan, pengayaan.

\subsection{Observasi atau Pengamatan}

Pengamatan dari observer terhadap pelaksanaan siklus II dilakukan dari tahap apersepsi sampai pelaksanaan evaluasi. Peneliti dibantu teman sejawat sebagai observer untuk memberikan penilaian selama proses penelitian berlangsung. Pemberian nilai berdasarkan kriteria penilaian yang di tetapkan, pengamat memberikan nilai dengan skor 5 kriteria sangat biak, 4 kriteria baik dan 3 kriteria cukup baik, 
2 kriteria kurang dan 1 kriteria sangat kurang. Adapun hasil ulangan formatif pada kompetensi dasar menulis paragraf deskripsi diperoleh data: (a) nilai tertinggi 90, (b) nilai terendah 70, (c) nilai rata-rata 80 , (d) jumlah peserta didik yang tuntas 18 atau $90 \%$,(e) jumlah peserta didik yang tidak tuntas 2 atau $10 \%$.

\subsection{Tahap Refleksi}

Berdasarkan analisis siklus II peneliti melakukan refleksi berdasarkan data yang diolah dari lembar pengamatan guru, lembar pencapaian indikator, lembar karakter mandiri dan hasil tes formatif. Adapun kesimpulan hasilnya sebagai berikut: (a) minat dan aktivitas siswa dalam pembelajaran mengalami peningkatan, (b) kesalahan diksi dan ejaan dalam penulisan kerangka karangan sudah dapat diminimalkan, (c) pembicaraan dalam diskusi kelompok sudah merata, (d) tidak ada siswa yang mendominasi pembicaraan, (e) tata tertib dan santun berdiskusi sudah dilaksanakan dengan baik, (f) adanya peningkatan kemampuan siswa dalam memecahkan masalah dengan cara bekerja sama dalam diskusi kelompok, (g) pemberdayaan foto hasil kunjungan wisata sebagai menulis paragraf deskripsi dapat meningkatkan pengalaman belajar menyimak, berbicara, membaca, dan menulis, (h) hasil tes formatif telah memenuhi target pencapaian indikator penelitian $\geq 75 \%$ yaitu pada siklus II pencapaian ketuntasan sampai 90\%. Dengan demikian perbaikan pembelajaran dinyatakan telah selesai dan telah mencapai hasil yang ditetapkan.

\section{b. Teknik Analisis Data}

Analisis data dalam penelitian ini menggunakan analisis deskriptif kuantitatif data yang telah diperoleh hasil analisis sebagai berikut:

a) Hasil tes akhir siklus

Dalam penelitian ini tes digunakan untuk mengetahui peningkatan pemahaman siswa tentang materi yang disyaratkan, nilai tes siswa harus mencapai $\geq 75$. Ketentuan ini disesuaikan dengan Ketuntasan Belajar Minimal (KKM) yang berlaku di sekolah. Adapun pedoman penilaian sebagai berikut:

1) Pedoman penilaian tes formatif

Untuk tes formatif pedoman penilaiannya menggunakan angkaangka, bentuk tes pilihan ganda, tiap satu nomor benar mendapat nilai 10 , tiap nomor salah mendapat nilai 0 , adapun nilai yang diperoleh jumlah jawaban benar x 10 .
2) Pedoman penghitungan persentase ketuntasan hasil belajar

Persentase ketuntasan hasil belajar dapat dihitung dengan pedoman rumus sebagai berikut: Persentase ketuntas belajar $=$

\section{$\frac{\sum \text { siswa mendapat nilai } \geq 75}{\sum \text { siswakeseluruhan }} \times 100 \%$}

3) Teknik penilaian kualitatif

yaitu teknik analisis data non tes meliputi lembar observasi guru, lembar observasi siswa, lembar observasi keaktifan siswa dalam pencapaian indikator, Dalam penilaian lembar observasi guru dan siwa peneliti menggunakan kriteria penilaian sebagai berikut:(1) skor 1 kriteria $\mathrm{E}$ artinya tidak baik,(2) skor 2 kriteria D artinya kurang baik, (3) skor 3 kriteria C artinya cukup baik, (4) skor 4 kriteria B artinya baik, (5) skor 5 kriteria A artinya sangat baik sekali

b) Kriteria keberhasilan

Taraf keberhasilan tindakan dari aspek siswa ditentukan dengan melihat hasil penggabungan portofolio dan tes siswa di akhir siklus. Nilai ketercapaian tindakan mempunyai rentangan antara 0-100. Kemudian akan dihitung berapa persen jumlah siswa yang tuntas dalam pembelajaran yaitu siswa yang mendapat nilai $\geq 75$.

\section{HASIL DAN PEMBAHASAN}

Hasil penelitian tindakan kelas pada siswa kelas IV SD 5 Lau Dawe Kabupaten Kudus sebagai berikut:

\section{a. Kondisi Awal}

Proses pembelajaran yang selama ini berlansung pada SD 5 Lau sebelum penelitian, pembelajaran bersifat konvensional, guru cenderung menyampaikan materi dengan ceramah, tanpa menggunakan alat peraga, siswa tanpa terlibat aktif dalam pembelajaran, sehingga terkesan pasif kurang kreatif bahkan cenderung bosan.

Melihat pembelajaran yang demikian, suasana pembelajaran tampak kaku, banyak siswa belum mencapai target Kriteria Ketuntasan Minimal (KKM) yang ditetapkan sebesar 75. Berdasarkan data yang peneliti peroleh dari hasil ulangan formatif pada kompetensi menulis paragraf deskripsi pada pratindakan diperoleh nilai tertinggi 80 , nilai terendah 60 , rata-rata klasikal 70 , peserta didik yang tuntas 7 orang atau $35 \%$, peserta didik yang belum tuntas 13 orang atau $65 \%$. 


\section{b. Hasil Penelitian Siklus I}

Penelitian Tindakan Kelas dengan cara pemberdayaan foto hasil kunjungan wisata siswa sebagai media pembelajaran ini merupakan upaya tindakan perbaikan untuk meningkatkan hasil belajar siswa, khususnya keterampilan menulis paragraf deskripsi. Pembahasan proses dan hasil belajar di bawah ini dimaksudkan untuk mengetahui seberapa besar keefektifan foto hasil kunjungan wisata diperdayakan sebagai media pembelajaran dan seberapa tinggi peningkatan hasil belajar kelas IV SD 5 Lau, setelah pemberdayaan foto tersebut. Adapun langkah-langkah peneliti deskripsikan sebagai berikut: (a) melalui diskusi dengan teman sebangku, peserta didik mengamati gambar tentang kegiatan sehari-hari yang sudah dibagikan oleh guru selajutnya menentukan topik dari foto hasil kunjungan wisata peserta didik tersebut, (b) peserta didik dapat menentukan subtopik dari sebuah objek gambar yang diamati dengan menentukan bagian-bagianya (manusia, hewan, tumbuhan, benda-benda lainya), (c) peserta didik dapat mengembangkan subtopik sesuai dengan situasi gambar, (d) peserta didik dapat merumuskan kalimat topik berdasarkan objek yang diamati, (e) peserta didik dapat menyusun kerangka paragraf melalui analisis dari topik ke subtopik dan pengembangannya sehingga menjadi sebuah kalimat kerangka yang runtut, (f) peserta didik dapat menyusun kalimat utama pada tiap paragraf, (g) peserta didik bersama guru, menyunting kalimat topik dan kerangka karangan sesuai EYD.

Indikator peningkatan prestasi belajar peserta didik ditentukan dengan tercapainya indikator penelitian yaitu tercapainya rata rata klasikal $80 \%$ dari nilai KKM yang ditetapkan. Berdasarkan hasil tes formatif pada siklus I, setelah dianalisis dapat diketahui bahwa dari 20 siswa, dengan KKM 75, yang memperoleh nilai lebih besar sama dengan KKM sebanyak 13 siswa dengan persentase $65 \%$, artinya tingkat ketuntasan pada siklus I baru $65 \%$. Berdasarkan indikator keberhasilan telah ditetapkan bahwa penelitian akan dinyatakan berhasil jika tingkat ketuntasan mencapai 75\%, adapun hasil pengamatan pada aspek minat diperoleh pada apersepsi rata-rata skor 3,0 atau $60 \%$ dari skor maksimal 5,0 dan skor tuntas 4,0 artinya respon siswa pada kegiatan awal saat guru memberikan stimulus keterkaitan pada materi yang akan dipelajari, kurang memuaskan. Pada kegiatan eksplorasi skor rata-rata 3,6 dengan ketuntasan $72 \%$, angka ini menunjukkan bahwa kegiatan eksplorasi mencapai kategori telah tuntas. Pada kegiatan elaborasi skor rata-rata 3,3 dengan persentase $66 \%$ artinya proses pembelajaran yang terurai dalam kegiatan elaborasi belum mencapai batas tuntas. Pada kegiatan konfirmasi, memperoleh skor 4,0 dengan persentase 80 artinya pada proses pembelajaran yang terangkum dalam kegiatan konfirmasi telah mencapai ketuntasan. Pada kegiatan penutup, mempreoleh skor 3,6 dengan persentase $72 \%$ artinya pada pembelajaran yang terangkum pada kegiatan penutup mencapai batas ketuntasan.

\section{c. Hasil Penelitian Siklus II}

Penelitian pada siklus II dilaksanakan karena pada pelakanaan Siklus I hasil Prestasi dan minat yang diharapkan dari penelitian belum tercapai Untuk itu siklus II dilaksanakan memperbaiki kekurangan pada siklus I. Pembelajaran dengan pemberdayaan foto sebagai media menulis paragraf deskripsi. Pemberdayaan foto hasil kunjungan wisata peserta didik kelas IV SD 5 Lau sebagai media pembelajaran menulis paragraf deskripsi dengan langkah-langkah: (a) melalui membaca contoh karangan deskripsi, peserta didik menyebutkan ciri-ciri karangan deskripsi, (b) berdasarkan pengamataan foto peserta didik dapat menentukan subtopik dari sebuah objek foto yang diamati dengan menentukan bagian bagianya (manusia, hewan, tumbuhan, bendabenda lainya), (c) peserta didik dapat menyusun kerangka paragraf melalui analisis dari topik ke subtopik dan pengembanganya sehingga menjadi sebuah kalimat kerangka yang runtut, (d) peserta didik dapat menyusun kalimat pengembang pada tiap paragraf, (e) peserta didik dapat memilih diksi berdasarkan gambar objek, (f) peserta didik dapat menyunting kalimat paragraf sesuai EYD, (g) peserta didik dapat menyusun paragraf sehingga membentuk karangan utuh, (h) peserta didik menuliskan judul karangan yang tepat untuk karangan yang ditulisnya, (i) peserta didik bersama guru, menyunting kalimat paragraf sesuai EYD, (j) menyusun karangan deskripsi berdasarkan hasil penyuntingan diksi.

Adapun hasil penelitian yang signifikan dari kondisi awal persentase ketuntasan hanya $35 \%$ dari 20 siswa hanya 7 siswa yang tuntas, pada siklus I dengan penerapan model pemberdayaan foto hasil kunjungan wisata terjadi perubahan tingkat ketuntasan menjadi $65 \%$ dan pada siklus II tingkat ketuntasan menjadi $90 \%$. Jadi penerapan model model pemberdayaan foto hasil kunjungan wisata 
dapat meningkatkan hasil belajar siswa kelas IV SD 5 Lau pada semester II tahun 2016/2017.

\section{Penutup}

\section{a. Simpulan}

Berdasarkan pembahasan hasil PTK tentang pemberdayaan foto hasil kunjungan wisata peserta didik sebagai media pembelajaran menulis paragraf deskripsi dapat disimpulkan bahwa kemampuan peserta didik menulis kerangka karangan deskripsi pada siklus I dapat dikatakan baik karena semua siswa kelas IV yang berjumlah 20 orang berhasil mencapai Kriteria Ketuntasan Minimal (KKM) dengan nilai rata-rata kelas 77 . Kemampuan siswa mengembangkan kerangka karangan menjadi paragraf deskripsi pada siklus tindakan II dapat disebut baik karena siswa kelas IV SD 5 Lau yang berjumlah 20 orang berhasil mencapai KKM yang ditetapkan yaitu 75 dengan nilai rata-rata79 atau meningkat 2,0 dari tindakan I. Foto hasil kunjungan wisata peserta didik sangat efektif diberdayakan sebagai media pembelajaran menulis paragraf deskripsi karena terbukti meningkatkan persentase ketuntasan belajar serta perolehan nilai hasil belajar jika dibandingkan dengan sebelum pelaksanaan PTK. Ketuntasan belajar secara klasikal meningkat $25 \%$, dari $65 \%$ menjadi $90 \%$. Dengan demikian, pembelajaran menulis dengan memperdayakan foto hasil kunjungan wisata peserta didik dapat disebut cukup berhasil karena ketuntasan belajar secara individu dan klasikal tercapai. Pembelajaran menulis dengan media foto memberi peluang kepada siswa untuk aktif mengamati unsurunsur foto tersebut sehingga minat dan perhatian siswa meningkat, pembelajaran terasa menyenangkan dan suasana kelas menjadi kondusif. Pembelajaran menulis paragraf deskripsi dengan memberdayakan foto hasil kunjungan wisata dapat meningkatkan aktivitas. Model pembelajaran dengan memberdayakan foto hasil kunjungan wisata sebagai media pembelajaran, mampu meningkatkan keterampilan menyimak, berbicara, membaca, dan menulis.

\section{b. Saran}

Berkaitan dengan fokus pembahasan dalam PTK ini, yakni pemberdayaan foto hasil kunjungan wisata peserta didik sebagai media pembelajaran untuk meningkatkan hasil belajar, berikut ini dikemukakan beberapa saran: (a) dalam pelaksanaan proses belajar mengajar, para guru seharusnya mengeksplorasi kreativitas dan berinovasi untuk meningkatkan kualitas pembelajaran. Langkah pertama yang perlu dilakukan adalah menciptakan budaya baca di kalangan guru. Karena itu, sekolah perlu mengalokasikan dana untuk pengadaan berbagai bahan bacaan, baik yang berkaitan dengan bidang kajian perbidang studi maupun aneka pustaka yang memperluas pengetahuan dan memperkaya wawasan guru. Dengan bekal ini, guru akan mampu meningkatkan mutu layanan edukatifnya, (b) para rekan guru semestinya termotivasi untuk mengganti teknik pembelajaran yang monoton dan searah dengan teknik pembelajaran yang menarik sehingga siswa memperoleh pengalaman belajar yang banyak dan bermacam-macam, misalnya model pembelajaran menulis dengan media foto.

\section{DAFTAR PUSTAKA}

Ahsin, Muhammad Nur. 2016. Peningkatan Keterampilan Menulis Karangan Narasi Dengan Menggunakan Media Audiovisual dan Metode Quantum Learning. Jurnal Refleksi Edukatika, 6(2): 158-171.

Andayani, dkk. 2017. Pemantapan Kemampuan Professional. Jakarta: Universitas Terbuka

Badan Standar Pendidikan Nasional. 2013. Peraturan Menteri Pendidikan Nasional No. 22 Tentang Standar Isi. Jakarta: Balai Pustaka

Harjanto. 2009. Media Pembelajaran. Solo: Tiga Serangkai.

Hastomo. 2007. Pedoman Menggarang Pada Siswa. Surabaya: Grafika Media.

Karso. 2015. Belajar dan Pembelajaran. Semarang: UNNES.

Setiadi, Gunawan. 2014. Petunjuk Praktis Pelaksanaan PTK untuk Guru. Modul. Tidak diterbitkan.

Sugiyono. 2007. Metode Penelitian Pendidikan (Pendekatan Kuantitatif, Kualitatif, dan $R \& D)$. Bandung: Alfabeta.

2016. Metode Penelitian Pendidikan (Pendekatan Kuantitatif, Kualitatif, dan $R \& D)$. Bandung: Alfabeta. 
S. Margareta. 2013. Pembelajaran Menulis Untuk Anak SD. Semarang: UNNES.

Smith. 2009. Ilmu Pendidikan. Jakarta: Gramedia.

Suhito. 2015. Prestasi Belajar. Semarang: UNNES.

Surbekti, Sri. 2009. Lancar Bahasa Indonesia 3 BSE. Jakarta: Balai Pustaka.
Suryati, M. 2010. Menulis Karangan Deskripsi, Semarang: PT Begawan Ilmu.

Susanto, Ahmad. 2013. Teori Belajar dan Pembelajaran di Sekolah Dasar. Jakarta: PT Prenadamedia Group.

Tarigan. 2011. Menulis. Bandung: Angkasa.

Wardani. 2015. Penelitian Tindakan Kelas. Jakarta: Universitas Terbuka. 